\title{
Is there a link between polycystic ovary syndrome and non-thyroidal illness syndrome?
}

\section{Polikistik over sendromu ve tiroid dışı hastalık sendromu arasında bir bağlantı var mı?}

Melia Karaköse ${ }^{1}$, Erman Çakal ${ }^{1}$, Oya Topaloğlu' ${ }^{1}$, Müyesser Sayki Arslan ${ }^{1}$, Zeynep Giniş², Mustafa Şahin ${ }^{3}$, Tuncay Delibaş ${ }^{1}$

'Department of Endocrinology and Metabolism, Dıskapı Ylldirm Beyazıt Training and Research Hospital, Ankara, Turkey

2Department of Biochemistry, Dışkapı Yıldırım Beyazım Training and Research Hospital, Ankara, Turkey

${ }^{3}$ Department of Endocrinology and Metabolism, Ankara University School of Medicine, Ankara, Turkey

\section{Abstract}

Objective: The aim of this study was to determine the frequency of non-thyroidal illness syndrome (NTIS) in patients with polycystic ovary syndrome (PCOS).

Material and Methods: During a 6-month period, 52 patients with PCOS were recruited for this cross-sectional study. The control group included 68 age-matched female volunteers. Serum free triiodothyronine (fT3), free thyroxine (fT4), thyroid stimulating hormone (TSH), anti-thyroperoxidase antibody (anti-TPO Ab), and anti-thyroglobulin antibody (anti-Tg Ab) were measured.

Results: The TSH level in the PCOS patients and controls did not differ significantly $(1.9 \pm 1.2 \mu \mathrm{IU} / \mathrm{mL}$ vs. $1.8 \pm 0.9 \mu \mathrm{IU} / \mathrm{mL}, \mathrm{p}>0.05)$. Serum fT3 and fT4 levels in the controls were significantly lower than those in the PCOS patients (fT3: $2.7 \pm 0.3 \mathrm{pg} / \mathrm{mL}$ vs. $2.9 \pm 0.3 \mathrm{pg} / \mathrm{mL}, \mathrm{p}=0.02$; fT4: $1.0 \pm 0.1 \mathrm{ng} / \mathrm{dL}$ vs. $1.1 \pm 0.1 \mathrm{ng} / \mathrm{dL}, \mathrm{p}=0.03$ ). The Hs-CRP (high-sensitivity C-reactive protein) level in the PCOS patients was significantly higher than in the controls $(3.5 \pm 4.9 \mathrm{mg} / \mathrm{L}$ vs. $1.7 \pm 2.7 \mathrm{mg} / \mathrm{L}, \mathrm{p}=0.03)$. A statistically significant relationship was observed between Hs-CRP and fT4 $(r=0.245, p=0.015)$. However, NTIS was not observed in either group.

Conclusion: Thyroid function abnormalities could be observed in PCOS; however, NTIS was not noted in the present study despite the inflammatory state of the PCOS patients.

(J Turkish-German Gynecol Assoc 2013; 14: 216-20)

Key words: Polycystic ovary syndrome, non-thyroidal illness syndrome, inflammation, hormones

Received: 05 September, 2013

Accepted: 22 September, 2013
Özet

Amaç: Bu çalışmanın amacı, polikistik over sendromu (PKOS) olan hastalarda tiroid dışı hastalık sendromunun (NTIS) sıklığını tespit etmektir.

Gereç ve Yöntemler: PKOS'lu 52 hasta 6 aylık bir dönemde bu kesitsel çalışmaya alındı. Kontrol grubuna yaş uyumlu 68 gönüllü kadın dahil edildi. Serum serbest triyodotironin (sT3), serbest tiroksin (sT4), tiroid uyarıcı hormon (TSH), anti-tiroperoksidaz antikoru (anti-TPO $\mathrm{Ab})$ ve anti-tiroglobulin antikoru (anti-Tg Ab ) ölçüldü.

Bulgular: PKOS hastalarında ve kontrol grubunda TSH düzeyinde $(1.9 \pm 1.8$ vs. $1.2 \mu \mathrm{IU} / \mathrm{mL} \pm 0.9 \mu \mathrm{IU} / \mathrm{mL}, \mathrm{p}>0.05)$ anlamlı fark yoktu. Kontrol grubunda serum sT3 ve sT4 düzeyleri PKOS hastalarınınkinden anlamlı olarak daha düşüktü (fT3: $2.7 \pm 0.3 \mathrm{pg} / \mathrm{mL}$ vs. $2.9 \pm 0.3 \mathrm{pg} / \mathrm{mL}$, $\mathrm{p}=0.02$; fT4: $1.0 \pm 0.1 \mathrm{ng} / \mathrm{dL}$ vs. $1.1 \pm 0.1 \mathrm{ng} / \mathrm{dL}, \mathrm{p}=0.03$ ). Hs-CRP (yüksek hassas C-reaktif protein) ve sT4 arasında istatistiksel olarak anlamlı ilişki gözlendi $(\mathrm{r}=0.245, \mathrm{p}=0.015)$. Ancak NTIS iki grupta da gözlenmedi.

Sonuç: Tiroid fonksiyon bozuklukları PKOS'ta gözlenebilir ancak PKOS hastalarındaki inflamatuar duruma rağmen bu çalışmada NTIS tespit edilmedi.

(J Turkish-German Gynecol Assoc 2013; 14: 216-20)

Anahtar kelimeler: Polikistik over sendromu, tiroid dışı hastalık sendromu, inflamasyon, hormonlar

Geliş Tarihi: 05 Eylül 2013

Kabul Tarihi: 22 Eylül 2013

\section{Introduction}

Polycystic ovary syndrome (PCOS) is probably the most common endocrinopathy in women of reproductive age, and is characterised by anovulation, hyperandrogenaemia, and frequently insulin resistance (IR). It is associated with an increased risk of type 2 diabetes mellitus (T2DM) (1-3).The serum plasminogen activator inhibitor-1 (PAI-1) (4), C-reactive protein (CRP) $(5,6)$, advanced glycation end-products (AGEs) (7) and endothelin-1 (8) levels are all elevated in PCOS patients. These markers are known to contribute to atherogenesis and chronic inflammation (9-12).

The first study to examine low-grade chronic inflammation in women with PCOS via the measurement of CRP was conducted in 2001 (13). The researchers reported that the CRP concentration was elevated in women with PCOS. PCOS patients were reported to exhibit higher mean serum tumour necrosis factor- $\alpha$ (TNF- $\alpha$ ) (14), soluble intracellular adhesionmolecule-1 (sICAM-1), and sE-selectin levels (15).

During many chronic illnesses, some aspects of thyroid hormone metabolism may change, which is collectively known as non-thyroidal illness syndrome (NTIS). Non-thyroidal illness is characterised by a decrease in the serum T3 level and it is thought that decreased extrathyroidal conversion of $\mathrm{T} 4$ to 
T3 is a primary mechanism underlying the syndrome (16-19). Several pathophysiological mechanisms have been considered and experimental data suggest that pro-inflammatory cytokines play a role in NTIS (20-23).

The most common NTIS hormonal profile is characterised by low peripheral T3 or free T3 (fT3), and an elevated reverse T3 (rT3) concentration; free T4 (fT4) and thyroid-stimulating hormone (TSH) levels are generally normal.

The literature includes detailed reports the on relationship between NTIS and chronic illnesses such as rheumatoid arthritis (RA), systemic lupus erythematosus (SLE), etc. $(24,25)$; however, to date, no systematic analysis of NTIS in women with PCOS has been undertaken. As such, the present study aimed to investigate the frequency of NTIS in PCOS patients.

\section{Material and Methods}

The study included the patients diagnosed as PCOS according to 2003 Rotterdam criteria (26) and followed-up at our Hospital, Department of Endocrinology and Metabolic Diseases, between October 2011 and March 2012. The control group consisted of 68 healthy female volunteers. Patients with a chronic disease other than PCOS, including RA, SLE, DM, hyperprolactinaemia, hypertension, and thyroid illness, and infectious diseases, and hepatic or renal disorders were excluded. Patients that used any drug during the previous 3 months, including oral contraceptive pills, antihyperlipidaemics, and drugs that affect insulin sensitivity were also excluded. All patients and controls underwent anamnesis and physical examination. The study protocol was approved by the Ethics Committee of our hospital and all the participants provided written informed consent.

Allpatients and controls underwent physical examination, anthropometric measurement and biochemical screening. The waist/ hip ratio and body mass index (BMI) were calculated. Fasting blood samples were obtained in the morning between 08:00 and 11:00, during the follicular phase of each participant's menstrual cycle. The fasting serum insulin level was measured using the chemiluminescent immunoassay method (Advia Centaur XP, Siemens Healthcare Diagnostics Inc., Tarrytown, USA). The estimate of insulin resistance was calculated using the HOMA-IR index. TSH, fT3 and fT4 were measured via chemiluminescentmicroparticle immunoassay (Abbott, Architect i2000, Abbott Laboratories Diagnostics Division, IL, USA). Antithyroglobulin antibody (anti-Tg Ab) and anti-thyroperoxidase antibody (anti-TPO Ab) were measured via chemiluminescent competitive immunoassay (Advia centaur XP, Siemens, Tarrytown, USA). Reference limits were as follows: fT3: 1.71$3.71 \mathrm{pg} / \mathrm{mL}$; fT4: $0.7-1.48 \mathrm{ng} / \mathrm{dL}$; TSH: $0.35-4.94 \mu \mathrm{IU} / \mathrm{mL}$; anti-Tg Ab: 0-60 IU/mL; anti-TPO Ab: 0-57 IU/mL. Anti-Tg Ab and antiTPO $\mathrm{Ab}$ concentrations $>60 \mathrm{IU} / \mathrm{mL}$ and $>57 \mathrm{IU} / \mathrm{mL}$, respectively, were considered positive.

The statistical analysis was performed with the SPSS statistical software (version 16; SPSS, Chicago, IL, USA). Normality of the variables was tested by Kolmogorov-Smirnov test. Differences between groups were analysed by one way analysis of variance or Mann-Whitney U-test when appropriate. Frequencies were analysed by $\chi^{2}$. Correlations between variables were performed using Spearman's rho correlation coefficient. Results are expressed as mean $\pm \mathrm{SD}$. A probability value of 0.05 was considered to be statistically significant.

\section{Results}

The study included 52 PCOS patients (mean age of $24.4 \pm 10.5$ years) and 68 controls (mean age of $26.5 \pm 65$ years). The general characteristics of the patients and controls are presented in Table 1.

There were no significant differences in age, BMI, or waist/hip ratio between the patient and control groups. Fasting blood glucose and HDL-C (high density cholesterol) did not differ significantly between the groups. The total cholesterol, LDL-C (low density cholesterol), and triglyceride levels were significantly higher in the PCOS patients than in the controls. Insulin resistance, as calculated by HOMA-IR (Homeostasis Model of Assessment - Insulin Resistance), was higher in the PCOS patients than that in the controls $(4.06 \pm 3.4$ vs. $2.3 \pm 1.6$, respectively; $p=0.0001)$. The Hs-CRP level in the PCOS patients was significantly higher than that in the controls $(3.5 \pm 4.9 \mathrm{mg} / \mathrm{L}$ vs. $1.7 \pm 2.7 \mathrm{mg} / \mathrm{L}$, respectively; $\mathrm{p}=0.03$ ).

The anti-TPO Ab level was measured in all 52 PCOS patients and 67 of the 68 randomly selected controls. Mean \pm SD serum anti-TPO Ab in the PCOS patients and controls was $134 \pm 254 \mathrm{IU}$ $\mathrm{IU} / \mathrm{mL}$ and $169 \pm 300 \mathrm{IU} / \mathrm{mL}$, respectively. The serum anti-Tg Ab level was measured in all 52 patients and 66 of the 68 controls. The mean \pm SD of serum anti- TG Ab in PCOS patients and controls was $56 \pm 83$ and $70 \pm 77 \mathrm{IU} / \mathrm{mL}$, respectively. There was no significant difference between patients and the control group in terms of anti-TPO Ab levels and anti-TG Ab levels $(p=0.49$ and $\mathrm{p}=0.324$, respectively).

The control group had a higher prevalence of positive anti-Tg Ab than PCOS (24 vs. 15\%); the divergence was not statistically

Table 1. The general characteristics of the PCOS patients and controls

\begin{tabular}{|c|c|c|c|}
\hline & $\begin{array}{c}\text { Patients } \\
(n=52)\end{array}$ & $\begin{array}{c}\text { Controls } \\
(n=68)\end{array}$ & $\mathbf{p}$ \\
\hline Age (years) & $24.4 \pm 10.5$ & $26.5 \pm 6.5$ & $>0.05$ \\
\hline BMI $\left(\mathrm{kg} / \mathrm{m}^{2}\right)$ & $26.5 \pm 6.1$ & $24.8 \pm 4.9$ & $>0.05$ \\
\hline Waist/hip ratio & $0.8 \pm 0.1$ & $0.8 \pm 0.08$ & $>0.05$ \\
\hline FBG (mg/dL) & $85 \pm 10$ & $82 \pm 12$ & $>0.05$ \\
\hline $\mathrm{TC}(\mathrm{mg} / \mathrm{dL})$ & $176 \pm 35$ & $163 \pm 27$ & 0.022 \\
\hline TG (mg/dL) & $111 \pm 69$ & $85 \pm 34$ & 0.010 \\
\hline LDL-C (mg/dL) & $103.4 \pm 28$ & $92.8 \pm 27$ & 0.044 \\
\hline HDL-C (mg/dL) & $53 \pm 14$ & $54 \pm 12$ & $>0.05$ \\
\hline HOMA-IR (\%) & $4.06 \pm 3.4$ & $2.3 \pm 1.6$ & 0.0001 \\
\hline HsCRP (mg/L) & $3.5 \pm 4.9$ & $1.7 \pm 2.7$ & 0.030 \\
\hline \multicolumn{4}{|c|}{$\begin{array}{l}\text { PCOS: Polycystic ovary syndrome; BMI: Body mass index; TC: Total cho- } \\
\text { lesterol; FBG: Fasting blood glucose; HDL-C; High density cholesterol; } \\
\text { LDL-C: Low density cholesterol; TG: Triglyceride; HOMA-IR: Homeosta- } \\
\text { sis Model of Assessment - Insulin Resistance; HsCRP: high-sensitivity } \\
\text { C-reactive protein }\end{array}$} \\
\hline
\end{tabular}


significant $(p=0.17)$. The prevalence of subjects with positive anti-TPO $\mathrm{Ab}$ in the patient and control groups was 44 and $73 \%$, respectively; it was significantly higher in control group $(\mathrm{p}=0.01)$.

NTIS was not observed in either group. The TSH level in the patient and control groups did not differ significantly $(1.9 \pm 1.2 \mu \mathrm{IU} / \mathrm{mL}$ vs. $1.8 \pm 0.9 \mu \mathrm{IU} / \mathrm{mL}, \mathrm{p}=0.475)$. The serum fT3 and fT4 levels in the control group were significantly lower than in the patient group (fT3: $2.7 \pm 0.3 \mathrm{pg} / \mathrm{mL}$ vs. $2.9 \pm 0.3 \mathrm{pg} / \mathrm{mL}, \mathrm{p}=0.02$; fT4: $1.0 \pm 0.1 \mathrm{ng} / \mathrm{dL}$ vs. $1.1 \pm 0.1 \mathrm{ng} / \mathrm{dL}, \mathrm{p}=0.03)$. The thyroid tests of the PCOS patients and controls are presented in Table 2.

A statistically significant relationship was found between HOMAIR and fT3 ( $\mathrm{r}=0.304, \mathrm{p}=0.01)$, Hs-CRP $(\mathrm{r}=0.208, \mathrm{p}=0.046)$, and age $(r=-0.286, p=0.03)$. A statistically significant relationship was found between Hs-CRP and fT4 $(r=0.245, p=0.015)$, HOMA-IR $(r=0.208, p=0.046)$, triglyceride $(r=0.358, p=0.0001)$ and total cholesterol $(\mathrm{r}=0.224, \mathrm{p}=0.029)$.

\section{Discussion}

Low-grade chronic inflammation in PCOS is indicated by the elevation of several markers, including the CRP level $(5,13,15$, 27-29), TNF- $\alpha$ (14), inflammatory cytokines (interleukin-6 and interleukin-18) (30), and leukocyte count (31). Data concerning the potential role of deiodinases in the pathogenesis of NTIS are inconsistent. The generally accepted view has been that extrathyroidal conversion of T4 to T3 is diminished in patients with illnesses due to a decrease in both hepatic/renal D1 activity and skeletal muscle D2 activity (32-34). It was suggested that, together, these modifications in deiodinase expression could be a major factor involved in causing the low T3 concentration that is associated with NTIS. The trigger for these changes in deiodinase expression has been attributed to an increase in proinflammatory cytokines, which often occurs in NTIS (35-39).

In the present study, the frequency of NTIS in both groups was the same, and the TSH level in the patient and control groups did not differ significantly; however, serum fT3 and fT4 levels in the controls were significantly lower than those in the patients. Furthermore, the Hs-CRP level in the PCOS patients was significantly higher than that in the controls, and a statistically significant relationship was noted between Hs-CRP and fT4.

Martocchia et al. (40) studied fT3, fT4, TSH, and CRP levels in 41 NTIS patients and reported that the serum fT3 level was higher

Table 2. The thyroid test of the PCOS patients and controls

\begin{tabular}{|l|c|c|c|}
\hline & $\begin{array}{c}\text { Patients } \\
(\mathbf{n = 5 2 )}\end{array}$ & $\begin{array}{c}\text { Controls } \\
(\mathbf{n = 6 8 )}\end{array}$ & $\mathbf{p}$ \\
\hline fT3 (pg/mL) & $2.9 \pm 0.3$ & $2.7 \pm 0.3$ & 0.02 \\
\hline fT4 (ng/dL) & $1.1 \pm 0.1$ & $1.0 \pm 0.1$ & 0.03 \\
\hline TSH $(\mu \mathrm{IU} / \mathrm{mL})$ & $1.9081 \pm 1.1643$ & $1.7695 \pm 0.9$ & $>0.05$ \\
\hline Anti-TG Ab Positive (\%) & $15 \%$ & $24 \%$ & $>0.05$ \\
\hline Anti-TPO Ab Positive (\%) & $44 \%$ & $73 \%$ & 0.01 \\
\hline
\end{tabular}

PCOS: Polycystic ovary syndrome; fT3: free triiodothyronine; fT4: free thyroxine; TSH: thyroid stimulating hormone; Anti-TG Ab: anti-thyroglobulin antibody; Anti-TPO Ab: anti-thyroperoxidase antibody; Values are shown as mean $\pm \mathrm{SD}$. and the fT4 level was lower in the NTIS patients than in the controls, and that the serum TSH level did not differ between the groups. Moreover, CRP and FT4 concentrations were positively associated $(\mathrm{p}<0.01)$.

Both anti-TPO Ab and anti-Tg Ab levels were higher in the control group than in PCOS patients; however, the difference was not significant. The prevalence of positivity of anti-TPO Ab and anti-Tg Ab were higher in the control group than in the PCOS group. However, there was a statistically significant difference only in terms of prevalence of anti-TPO Ab positivity $(p=0.01)$. Kachuei et al. (41) showed that PCOS patients had higher antiTPO Ab levels than controls $(\mathrm{p}<0.05)$, but that serum TSH and anti-Tg Ab levels did not differ significantly. Although the frequency of anti-Tg Ab and anti-TPO Ab positivity was higher in the PCOS patients than in the control group, the difference was not significant ( $p>0.05)$. Janssen et al. (42) observed that TSH, anti-TPO and anti-Tg levels were significantly higher in PCOS patients than in controls.

In conclusion, the present findings indicate that PCOS is a chronic inflammatory disease associated with elevated Hs-CRP, but, on the contrary, NTIS was not detected. Thyroid function tests which have small deviations should not be considered in relation to the NTIS in patients with PCOS. As a result, other thyroid diseases should be investigated more carefully in such situations.

\section{Ethics Committee Approval: N/A.}

Informed Consent: $N / A$.

Peer-review: Externally peer-reviewed.

Author contributions: Concept - M.K., T.D.; Design - M.K., T.D.; Supervision - E.C., M.S., T.D.; Resource - M.K., O.T., T.D.; Materials - M.K., Z.G.; Data Collection\&/or Processing - M.K., M.S.A., O.T.; Analysis\&/or Interpretation - M.K.,O.T.; Literature Search-M.K., E.Ç., M.S.A.; Writing - M.K., O.T.; Critical Reviews E.C.., M.S.., T.D.

Conflict of Interest: The authors declared no conflict of interest. Financial Disclosure: The authors declared that this study received no financial support.

\section{References}

1. Diamanti-Kandarakis E, Kouli CR, Bergiele AT, Filandra FA, Tsianateli TC, Spina GG, et al. A survey of the polycystic ovary syndrome in the Greek island of Lesbos: hormonal and metabolic profile. J Clin Endocrinol Metab 1999; 84: 4006-111. [CrossRef]

2. Ehrmann DA, Bames RB, Rosenfild RL, Cavaghan MK, Imperial J. Prevalence of impaired glucose tolerance and diabetes in women with polycystic ovary syndrome. Diabetes Care 1999; 22: 141-6. [CrossRef]

3. Orio F Jr, Palomba S, Spinelli L, Cascella T, Tauchmanova L, Zullo $\mathrm{F}$, et al. The cardiovascular risk of young women with polycystic ovary syndrome: an observational, analytical, prospective case-control study. J Clin Endocrinol Metab 2004; 89: 3696-701. [CrossRef]

4. Diamanti-Kandarakis E, Palioniko G, Alexandraki K, Bergiele A, Koutsouba T, Bartzis M. The prevalence of $4 \mathrm{G} 5 \mathrm{G}$ polymorphism of plasminogen activator inhibitor-1 (PAI-1) gene in polycystic ova- 
rian syndrome and its association with plasma PAI-1 levels. Eur J Endocrinol 2004; 150: 793-8. [CrossRef]

5. Boulman N, Levy Y, Leiba R, Shachar S, Linn R, Zinder O, et al. Increased $\mathrm{C}$-reactive protein levels in the polycystic ovary syndrome: a marker of cardiovascular disease. J Clin Endocrinol Metab 2004; 89: 2160-5. [CrossRef]

6. Talbott EO, Zborowski JV, Boudreaux MY, McHugh-Pemu KP, Sutton-Tyrrell K, Guzick DS. The relationship between C-reactive protein and carotid intima-media wall thickness in middle-aged women with polycystic ovary syndrome. J Clin Endocrinol Metab 2004; 89: 6061-7. [CrossRef]

7. Diamanti-Kandarakis E, Piperi C, Kalofoutis A, Creatsas G. Increased levels of serum advanced glycation end-products in women with polycystic ovary syndrome. Clin Endocrinol (Oxf) 2005; 62: 37-43. [CrossRef]

8. Diamanti-Kandarakis E, Spina G, Kouli C, Migdalis I. Increased endothelin-1 levels in women with polycystic ovary syndrome and the beneficial effect of metformin therapy. J Clin Endocrinol Metab 2001; 86: 4666-73. [CrossRef]

9. Alexander RW. Inflammation and coronary artery disease. N Engl J Med 1994; 331: 468-9. [CrossRef]

10. Wilson PW, Kannel WB, Silbershatz H, D'Agostino RB. Clustering of metabolic factors and coronary heart disease. Arch Intern Med 1999; 159: 1104-9. [CrossRef]

11. Pai JK, Pischon T, Ma J, Manson JE, Hankinson SE, Joshipura K, et al. Inflammatory markers and the risk of coronary heart disease in men and women. N Engl J Med 2004; 351: 2599-610. [CrossRef]

12. Lee CD, Folsom AR, Nieto FJ, Chambless LE, Shahar E, Wolfe DA. White blood cell count and incidence of coronary heart disease and ischemic stroke and mortality from cardiovascular disease in African-American and white men and women. Am J Epidemiol 2001; 154: 758-64. [CrossRef]

13. Kelly CC, Lyall H, Petrie JR, Gould GW, Connell JM, Sattar N. Lowgrade chronic inflammation in women with polycystic ovarian syndrome. J Clin Endocrinol Metab 2001; 86: 2453-5. [CrossRef]

14. Gonzalez F, Thusu K, Abdel-Rahman E, Prabhala A, Tomani M, Dandona P. Elevated serum levels of tumor necrosis factor alpha in normal-weight women with polycystic ovary syndrome. Metabolism 1999; 48: 437-41. [CrossRef]

15. Diamanti-Kandarakis E, Paterakis T, Alexandraki K, Piperi C, Aessopos A, Katsikis I, et al. Indices of low-grade chronic inflammation in polycystic ovary syndrome and the beneficial effect of metformin. Hum Reprod 2006; 21: 1426-31. [CrossRef]

16. Koenig RJ. Regulation of type 1 iodothyroninedeiodinase in health and disease. Thyroid 2005; 15: 835-40. [CrossRef]

17. Bianco AC, Kim BW. Deiodinases: implications of the local control of thyroid hormone action. J Clin Invest 2006; 116: 2572-9. [CrossRef]

18. Gereben B, Zavacki AM, Ribich S, Kim BW, Huang SA, Simonides WS, et al. Cellular and molecular basis of deiodinase-regulated thyroid hormone signalling. Endocr Rev 2008; 29: 898-938. [CrossRef]

19. Kuiper GG, Kester MH, Peeters RP, Visser TJ. Biochemical mechanisms of thyroid hormone deiodination. Thyroid 2005; 15: 787-98. [CrossRef]

20. Van der Poll T, Romijn JA, Wiersinga WM, Sauerwein HP. Tumor necrosis factor: a putative mediator of the sick euthyroid syndrome in man. J Clin Endocrinol Metab 1990; 71: 1567-72. [CrossRef]

21. Stouthard JM, van der Poll T, Endert E, Bakker PJ, Veenhof $\mathrm{CH}$, Sauerwein HP, et al. Effects of acute and chronic interleukin-6 administration on thyroid hormone metabolism in humans. J Clin Endocrinol Metab 1994; 79: 1342-6. [CrossRef]
22. Corssmit EP, Heyligenberg R, Endert E, Sauerwein HP, Romijn JA. Acute effects of interferon-alpha administration on thyroid hormone metabolism in healthy men. J Clin Endocrinol Metab 1995; 80: 3140-4. [CrossRef]

23. Nagaya T, Fujieda M, Otsuka G, Yang JP, Okamoto T, Seo H. A potential role of activated NF-kappa B in the pathogenesis of euthyroid sick syndrome. J Clin Invest 2000; 106: 393-402. [CrossRef]

24. Al-Awadhi AM, Olusi S, Hasan EA, Abdullah A. Frequency of abnormal thyroid function tests in Kuwaiti Arabs with autoimmune diseases. Med PrincPract 2008; 17: 61-5. [CrossRef]

25. Antonelli A, Fallahi P, Mosca M, Ferrari SM, Ruffilli I, Corti A, et al. Prevalence of thyroid dysfunctions in systemic lupus erythematosus. Metabolism 2010; 59: 896-900. [CrossRef]

26. Rotterdam ESHRE/ASRM-Sponsored PCOS consensus workshop group. Revised 2003consensus on diagnostic criteria and long-term health risks related to polycystic ovary syndrome (PCOS). Hum Reprod 2004; 19: 41-7. [CrossRef]

27. Tarkun I, Arslan BC, Canturk Z, Türemen E, Sahin T, Duman C. Endothelial dysfunction in young women with polycystic ovary syndrome: relationship with insulin resistance and low-grade chronic inflammation. J Clin Endocrinol Metab 2004; 89: 5592-6. [CrossRef]

28. Engin-Ustün Y, Ustün Y, Meydanli MM, Kafkasli A, Yetkin G. Are polycystic ovaries associated with cardiovascular disease risk as polycystic ovary syndrome? Gynecol Endocrinol 2006; 22: 324-8. [CrossRef]

29. Cakal E, Ustun Y, Engin-Ustun Y, Ozkaya M, Kilinç M. Serum vaspin and C-reactive protein levels in women with polycystic ovaries and polycystic ovary syndrome. Gynecol Endocrinol 2011; 27: 491-5. [CrossRef]

30. Escobar-Morreale HF, Botella-Carretero JI, Villuendas G, Sancho J, San Millán JL. Serum interleukin-18 concentrations are increased in the polycystic ovary syndrome: relationship to insulin resistance and to obesity. J Clin Endocrinol Metab 2004; 89: 806-11. [CrossRef]

31. Orio F Jr, Palomba S, Cascella T, Di Biase S, Manguso F, Tauchmanovà $\mathrm{L}$, et al. The increase of leukocytes as a new putative marker of low-grade chronic inflammation and early cardiovascular risk in polycystic ovary syndrome. J Clin Endocrinol Metab 2005; 90: 2-5. [CrossRef]

32. Chopra IJ. Clinical review 86: euthyroid sick syndrome: is it a misnomer? J Clin Endocrinol Metab 1997; 82: 329-34. [CrossRef]

33. Peeters RP, Wouters PJ, van Toor H, Kaptein E, Visser TJ, Van den Berghe G. Serum 3,3',5'-triiodothyronine (rT3) and 3,5,3'-triiodothyronine/rT3 are prognostic markers in critically ill patients and are associated with postmortem tissue deiodinase activities. J Clin Endocrinol Metab 2005; 90: 4559-65. [CrossRef]

34. De Groot LJ. Non-thyroidal illness syndrome is a manifestation of hypothalamic-pituitary dysfunction, and in view of current evidence, should be treated with appropriate replacement therapies. Critical Care Clinics 2006; 22: 57-86. [CrossRef]

35. Boelen A, Platvoet-TerSchiphorst MC, Wiersinga WM. Soluble cytokine receptors and the low 3,5,30-triiodothyronine syndrome in patients with nonthyroidal disease. J Clin Endocrinol Metab 1995; 80: 971-6. [CrossRef]

36. Boelen A, Kwakkel J, Alkemade A, Renckens R, Kaptein E, Kuiper $\mathrm{G}$, Wiers, et al. Induction of type 3 deiodinase activity in inflammatory cells of mice with chronic local inflammation. Endocrinology 2005; 146: 5128-34. [CrossRef]

37. Hosoi Y, Murakami M, Mizuma H, Ogiwara T, Imamura M, Mori M. Expression and regulation of type II iodothyroninedeiodinase in cultured human skeletal muscle cells. J Clin Endocrinol Metab 1999; 84: 3293-300. [CrossRef] 
38. Jakobs TC, Mentrup B, Schmutzler C, Dreher I, Köhrle J. Proinflammatory cytokines inhibit the expression and function of human type I 5'-deiodinase in HepG2 hepatocarcinoma cells. Eur J Endocrinol 2002; 146: 559-66. [CrossRef]

39. Kwakkel J, van Beeren HC, Ackermans MT, Platvoet-Ter Schiphorst MC, Fliers E, Wiersinga WM, et al. Skeletal muscle deiodinase type 2 regulation during illness in mice. J Endocrinol 2009; 203: 263-70. [CrossRef]

40. Martocchia A, Cola S, Frugoni P, Indiano I, D'Urso R, Falaschi P. The burden of comorbidity and the C-reactive protein levels in nonth- yroidal illness syndrome with metabolic syndrome and atherosclerosis-related cardiovascular complications. Ann N Y Acad Sci 2010; 1193:164-6. [CrossRef]

41. Kachuei M, Jafari F, Kachuei A, Keshteli AH. Prevalence of autoimmune thyroiditis in patients with polycystic ovary syndrome. Arch Gynecol Obstet 2012; 285: 853-6. [CrossRef]

42. Janssen OE, Mehlmauer N, Hahn S, Offner AH, Gärtner R. High prevalence of autoimmune thyroiditis in patients with polycystic ovary syndrome. Eur J Endocrinol 2004; 150: 363-9. [CrossRef] 